Netherlands Journal of

Geosciences

www.cambridge.org/njg

\section{Editorial}

Cite this article: Bittmann F, Bungenstock F, and Wehrmann A. Drowned palaeo-

landscapes: archaeological and geoscientific research at the southern North Sea coast. Netherlands Journal of Geosciences, Volume 101, e3. https://doi.org/10.1017/njg.2021.15

Received: 19 November 2021

Accepted: 24 November 2021

Author for correspondence:

Felix Bittmann,

Email: bittmann@nihk.de

\title{
Drowned palaeo-landscapes: archaeological and geoscientific research at the southern North Sea coast
}

Felix Bittmann $^{1}\left(\mathbb{0}\right.$, Friederike Bungenstock $^{1}\left[\right.$ and Achim Wehrmann ${ }^{2}$

${ }^{1}$ Lower Saxony Institute for Historical Coastal Research, Wilhelmshaven, Germany and ${ }^{2}$ Senckenberg am Meer, Marine Research Department, Wilhelmshaven, Germany

The post-glacial development of the North Sea basin is characterised by a gradual retrogradation of the coastal zone and subsequent flooding of former landscapes under relative sea-level rise. Depositional processes resulted in the burial of coastal zone deposits and corresponding biocoenoses leading, in parts, to their preservation. Thus, the sedimentary sequences of the Wadden Sea coast, which preserve evidence of Pleistocene and Holocene landscapes including flora, fauna and traces of human settlements, are excellent archives for palaeoenvironmental reconstructions (Verhart, 2005; Van Ginkel et al., 2014; Vos et al., 2015).

However, only little is known about the former now submerged landscapes of the southern North Sea. The already known archaeological remains, spanning primarily the time from the Mesolithic to the modern era, are only the tip of the iceberg, and the vast majority of sites remain hidden beneath the surface and so are yet to be discovered. Nevertheless, much progress has been made in mapping the structure of the former landscapes by large-scale geophysical measurements (Flemming, 2004; Ward et al., 2006; Cowrie 2007; Selby 2009; Tappin et al., 2011; Sturt et al., 2013; Hepp et al., 2017). Particularly important in this regard was the joint research project 'Geopotential German North Sea (GPDN)' that aimed to reconstruct the Quaternary geology and to map the palaeo-topography of base layers in the German Bight (Reinhardt et al., 2010).

The results from multi-proxy methods and trans-disciplinary cooperation on post-glacial landscape development, sedimentary processes, sea-level and climate changes as well as prehistoric human settlement strategies are of particular relevance for the formulation and implementation of coastal protection measures. This approach has also been promoted by the COST Action TD0902 SPLASHCOS (Submerged Prehistoric Archaeology and Landscapes of the Continental Shelf, 2009-2013), which was funded by the EU and aimed to foster international research collaboration dealing with all aspects of underwater heritage (Bailey et al., 2020).

Following on from the projects referred to above, a multi-disciplinary and national research project 'WASA - The WAdden Sea as an Archive of landscape evolution, climate change and settlement history: exploration - analysis - predictive modelling' has been undertaken to reconstruct the dynamic palaeo-landscapes in the central Wadden Sea region, as a basis for predictive modelling of human settlement pattern and its impacts on the environment since the last glacial. In the WASA project, particular attention has been paid to geology, biology and archaeology. This and earlier research serve to underline the widely acknowledged importance of the Wadden Sea (a UNESCO World Heritage site), not only in terms of sedimentary dynamics but also from a human, cultural perspective.

The articles in this special issue are the outcome of an international colloquium held in September 2019 at the Hanse Wissenschaftskolleg - Institute for Advanced Study (HWK), Delmenhorst, Lower Saxony, in the framework of the WASA project. The articles present details of new developments and discuss the results of wide-ranging research along the southern North Sea coast by the participating specialists. A brief summary of the various contributions follows.

Schaumann et al. (2021) (The Middle Pleistocene to early Holocene subsurface geology of the Norderney tidal basin: new insights from core data and high-resolution sub-bottom profiling (Central Wadden Sea, southern North Sea)) deal with the Pleistocene strata below the Holocene sediments. These span at least two glacial-interglacial cycles. The results lead to a better understanding of the Quaternary stratigraphy of the central Wadden Sea as well as the influence of the subsurface geology on the architecture and evolution of tidal channels and thus provide a solid groundwork for the contributions that follow.

The following articles deal with sea-level rise and its consequences for the former landscape evolution and settlements.

Karle et al. (2021) (Holocene coastal landscape development in response to rising sea level in the Central Wadden Sea coastal region) reconstruct the palaeo-landscape for several time slices based on more than 1200 sediment cores and also the overall landscape development in the coastal area as determined by Holocene relative sea-level rise. They show how the Holocene 
landscape development and sedimentary facies types are controlled by local palaeo-topography, sea-level changes, sediment supply and accommodation space as well as the morpho-dynamic impact of channel shifts and their erosion base.

A detailed palaeo-landscape reconstruction is given for the Norderney back-barrier area by Elschner et al. (2021) (Microfauna- and sedimentology-based facies analysis for palaeolandscape reconstruction in the back-barrier area of Norderney (NW Germany)). These authors analyse foraminifers and ostracods in combination with sedimentological and geochemical parameters. They suggest that the spatial distribution of salt-marsh sediments is probably underestimated in palaeo-maps.

Bungenstock et al. (2021) (Holocene relative sea-level data for the East Frisian barrier coast, NW Germany, southern North Sea) present a local curve of relative sea-level rise for the island of Langeoog and calculate compaction rates of basal and intercalated peat samples.

Vos and Nieuwhof (2021) (Late-Holocene sea-level reconstruction (1200 BC-AD 100) in the Westergo terp region of the northern Netherlands) discuss relative sea-level data collected during excavations that facilitated reconstruction of mean high water in the region. Because this is also influenced by locally fluctuating tidal ranges, the possible reasons for the fluctuations and the implications for the local curve of relative sea-level rise are considered.

Based on botanical remains and extensive radiocarbon dating, distinct habitats which may have served as living areas for former peoples in the coastal area are reconstructed by Schlütz et al. (2021) (From dust till drowned: the Holocene landscape development at Norderney, East Frisian Islands). Changes in the course of relative sea-level rise over the relevant time periods are also discussed.

Related to the last-mentioned contribution, Becker and Siegmüller (2021) (The coastal lowland of northwestern Germany as an archive of Holocene landscape evolution: basis for a spatial evaluation of Stone Age settlement patterns in the Dornumer tidal basin) depicted the settlement pattern for Stone Age settlements taking into account potential landscape preferences based on vegetation, availability of freshwater, security, etc. For the spatial analysis, a palaeo-topography was developed; this helps to reconstruct the influence of flooding on settlement patterns.

Röbke et al. (2020) (Dyke failures in the Province of Groningen (Netherlands) associated with the 1717 Christmas flood: a reconstruction based on geoscientific field data and numerical simulations) describe the 1717 Christmas flood, a storm surge with catastrophic consequences, applying a numerical modelling approach. Such surges were regular occurrences after dikes were built, beginning in the eleventh century AD.

The volume is completed by new methodological aspects. Enters et al. (2021) (A new $\Delta \mathrm{R}$ value for the southern North Sea and its application in coastal research) present a new $\Delta \mathrm{R}$ value (correction factor) for the calibration of radiocarbon dates from marine environments affected by 'old' carbon, that is the so-called 'reservoir effect' which must be corrected for when calibrating radiocarbon dates.

Lee et al. (2021) (Facies characterisation of sediments from the East Frisian Wadden Sea (Germany): new insights from down-core scanning techniques) take a closer look at recorded facies using four non-destructive down-core scanning techniques: magnetic susceptibility (MS), X-ray computed tomography (CT), X-ray fluorescence (XRF) and digital photography. Their approach allows an observer-independent differentiation of the facies types and represents a first step towards automated and quantitatively reproducible facies classification.

Finally, Capperucci et al. (2022) (The WASA core catalogue of Late Quaternary depositional sequences in the central Wadden Sea - a manual for the core repository) give an overview on the different sediment facies and depositional conditions recorded in cores from their chosen study area, namely the environs around the island of Norderney. All core data will be archived by the World Data Center PANGAEA under the project name WASA (https://www.pangaea.de/?f.project=WASA).

The joint research project WASA was carried out in the context of the funding initiative 'Küsten und Meeresforschung in Niedersachsen' of the Ministry for Science and Culture of Lower Saxony and was financed by the 'Niedersächsisches Vorab' of the Volkswagen Stiftung, project VW ZN3197.

Our sincere thanks goes to all reviewers and the editorial staff especially the Editor in Chief of this issue, Johan ten Veen - of the Netherlands Journal of Geosciences. The Netherlands Journal of Geosciences Foundation is thanked for financial support that enabled the publication of this special issue.

\section{References}

Bailey, G., Galanidou, N., Peeters, H., Jöns, H. \& Mennenga, M., 2020. The archaeology of Europe's drowned landscapes. Springer International Publishing (Cham).

Becker, T. \& Siegmuiller, A., 2021. The coastal lowland of northwestern Germany as an archive of Holocene landscape evolution: basis for a spatial evaluation of Stone Age settlement patterns in the Dornumer tidal basin. Netherlands Journal of Geosciences 100: e5.

Bungenstock, F., Freund, H. \& Bartholomä, A., 2021. Holocene relative sealevel data for the East Frisian barrier coast, NW Germany, southern North Sea. Netherlands Journal of Geosciences 100: e16.

Capperucci, R.M., Bartholomä, A., Bungenstock, F., Enters, D., Karle, M. \& Wehrmann, A., 2022. The WASA core catalogue of Late Quaternary depositional sequences in the central Wadden Sea - a manual for the core repository. Netherlands Journal of Geosciences.

Cowrie Ltd. 2007. Historic environment guidance for the offshore renewable energy sector. Available at http://www.offshorewindfarms.co.uk/ Pages/Publications/Archive/Cultural_Heritage/Historic_environment_ g43354590/

Elschner, A., Scheder, J., Bungenstock, F., Bartholomä, A., Becker, T.M., Capperucci, R.M., Enters, D., Karle, M., Schlütz, F., Wehrmann, A., Hoffmann, G., 2021. Microfauna- and sedimentology-based facies analysis for palaeolandscape reconstruction in the back-barrier area of Norderney (NW Germany). Netherlands Journal of Geosciences 100: e4.

Enters, D., Haynert, K., Wehrmann, A., Freund, H. \& Schlütz, F., 2021. A new $\Delta \mathrm{R}$ value for the southern North Sea and its application in coastal research. Netherlands Journal of Geosciences 100: e1.

Flemming, N.C., 2004. Submarine prehistoric archaeology of the North Sea: Research priorities and collaboration with industry. CBA Research Report 141 (York).

Hepp, D.A., Warnke, U., Hebbeln, D. \& Mörz, T., 2017. Tributaries of the Elbe Palaeovalley: Features of a Hidden Palaeolandscape in the German Bight, North Sea. In: Bailey G.N., Harff J. \& Sakellariou D. (eds): Under the Sea: Archaeology and Palaeolandscapes of the Continental Shelf. Springer International Publishing (Cham): 211-222.

Karle, M., Bungenstock, F. \& Wehrmann, A., 2021. Holocene coastal landscape development in response to rising sea level in the Central Wadden Sea coastal region. Netherlands Journal of Geosciences 100: e12.

Lee, A.-S., Enters, D., Titschack, J. \& Zolitschka, B., 2021. Facies characterisation of sediments from the East Frisian Wadden Sea (Germany): New insights from down-core scanning techniques. Netherlands Journal of Geosciences 100: e8. 
Reinhardt, L., Krüger, A. \& Zeiler, M., 2010. Geopotenzial Deutsche Nordsee. Geowissenschaftliche Mitteilungen 41(2010): 6-16.

Röbke, B.R., Oost, A., Bungenstock, F., Fischer, P., Grasmeijer, B., Hadler, H., Obrocki, L., Pagels, J., Willershäuser, T., Vött, A., 2020. Dyke failures in the Province of Groningen (Netherlands) associated with the 1717 Christmas flood: a reconstruction based on geoscientific field data and numerical simulations. Netherlands Journal of Geosciences 99: e15.

Schaumann, R.M., Capperucci, R.M., Bungenstock, F., McCann, T., Enters, D., Wehrmann, A. \& Bartholomä, A., 2021. The Middle Pleistocene to early Holocene subsurface geology of the Norderney tidal basin: new insights from core data and high-resolution sub-bottom profiling (Central Wadden Sea, southern North Sea). Netherlands Journal of Geosciences 100: e15.

Schlïtz, F., Enters, D. \& Bittmann, F., 2021. From dust till drowned: the Holocene landscape development at Norderney, East Frisian Islands. Netherlands Journal of Geosciences 100: e7.

Selby, I. (ed.), 2009. MEPF 08/01 Outer Thames estuary regional environmental characterisation, Marine Aggregate Levy Sustainability Fund (MALSF).

Sturt, F., Garrow, D. \& Bradley, S., 2013. New models of North West European Holocene palaeogeography and inundation. Journal of Archaeological Science 40(2013): 3963-3976.

Tappin, D.R., Pearce, B., Fitch, S., Dove, D., Gearey, B, Hill, J.M., Chambers, C., Bates, R., Pinnion, J., Diaz Doce, D., Green, M., Gallyot, J., Georgiou, L.,
Brutto, D., Marzialetti, S., Hopla, E., Ramsay, E. \& Fielding, H., 2011. The Humber Regional Environmental Characterisation. British Geological Survey Open Report OR/10/54.

Van Ginkel, E., Reumer, J. \& Van Der Valk, B., 2014. Schatten van het Mammoetstrand. Over speuren in grondlagen, opgraven onder water en vissen naar fossielen. Havenbedrijf Rotterdam, Projectorganisatie Maasvlakte 2 (Rotterdam): $216 \mathrm{pp}$.

Verhart, L., 2005. A drowned land. Mesolithic from the North Sea floor. In: Louwe Kooijmans L.P., van den Broeke P.W., Fokkens H. \& van Gijn A.L. (eds): The prehistory of the Netherlands. Amsterdam University Press (Amsterdam): 157-160.

Vos, P.C., Bunnik, F.P.M., Cohen, K.M. \& Cremer, H., 2015. A staged geogenetic approach to underwater archaeological prospection in the Port of Rotterdam (Yantzehaven, Maasvlakte, The Netherlands): A geological and palaeoenvironmental case study for local mapping of Mesolithic lowland landscapes. Quaternary International 367: 4-31.

Vos, P.C. \& Nieuwhof, A., 2021. Late-Holocene sea-level reconstruction (1200 $\mathrm{BC}-\mathrm{AD}$ 100) in the Westergo terp region of the northern Netherlands. Netherlands Journal of Geosciences 100: e3.

Ward, I., Larcombe, P. \& Lillie, M., 2006. The dating of Doggerland - postglacial geochronology of the southern North Sea. Environmental Archaeology 11(2006): 207-218. 